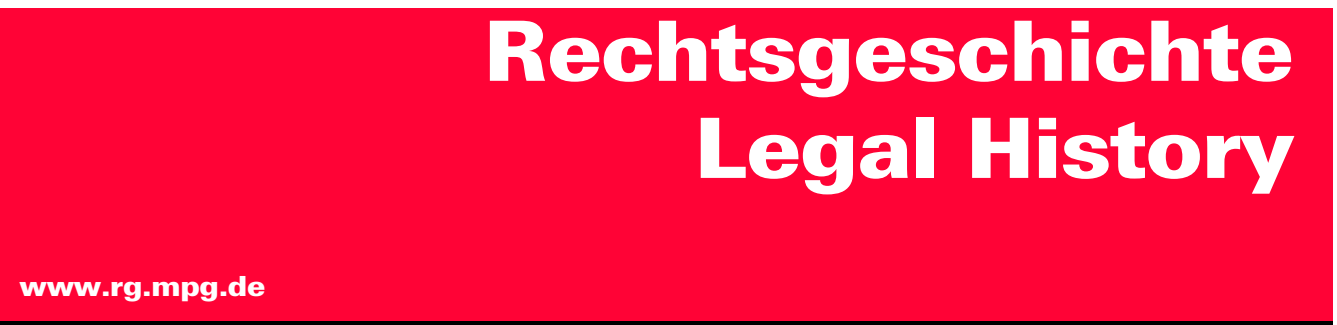

http://www.rg-rechtsgeschichte.de/rg27

Zitiervorschlag: Rechtsgeschichte - Legal History Rg 27 (2019)

$\operatorname{Rg} 272019 \quad 163-171$

http://dx.doi.org/10.12946/rg27/163-171

\title{
Cecilia Cristellon*
}

\section{The Roman Congregations and the Application of the Tametsi as an Instrument of Their Policies Towards Mixed Marriages in Europe (1563-1798)}




\section{Abstract}

The article analyses how the decrees of the Council of Trent regarding marriage were used by the Church of Rome as a tool to contrast mixed marriages in Early Modern Europe. It investigates how these decrees were evaded by local churches in order to administer a practice of confessional coexistence impossible to eradicate, and how they were manipulated by actors - even Protestants - to put an end to undesirable unions. It also presents the interpretation that the Church of Rome made of the Tametsi to resolve the age-old issue of mixed marriages in the Low Countries, issuing the Benedictine Declaration, later applied to other contexts with a strong Protestant presence - above all outside Europe. Although the Council of Trent claimed to have fixed a homogeneous and flawless nuptial ritual, the various local practices did not always adapt to it. Indeed, they bypassed it; sometimes refused it. This led parish priests and missionaries to turn to Rome for the resolution of concrete cases. The decisions taken for individual cases became a normative reference point. It was produced by the continuous interaction and negotiation with local churches and went on in fact to profoundly influence the sacramental rituality of marriages, which Tametsi had claimed were fixed and immutable.

Keywords: Mixed marriages, Tametsi, Roman Congregations, Netherlands 


\section{Cecilia Cristellon}

\section{The Roman Congregations and the Application of the Tametsi as an Instrument of Their Policies Towards Mixed Marriages in Europe (1563-1798)}

As is well known, in 1563 the Council of Trent affirmed the sacramental and unalterable nature of marriage, and fixed a ceremony that claims to be universal, going to attack very ancient wedding practices. It required the presence at a wedding of the parish priest of at least one of the spouses along with at least two witnesses; marriages celebrated without them were henceforth invalid. ${ }^{\mathbf{1}}$ The concrete cases and the various local practices, however, induce both lay and ecclesiastical to manipulate, circumvent, adapt these rules and the rite itself. The persistence of multiple customary rights, the competition of secular law and the various confessional churches gave rise to a context of multinormativity $^{2}$ which increased individual actors' space to maneuver and led the Roman Church to continual negotiations, re-elaborations and adaptation of its own doctrine depending on the context and the specific case with which it was confronted.

In this article I propose to analyse first of all how the decrees of the Council of Trent regarding marriage were used by the Church of Rome as a tool to contrast mixed marriages in Early modern Europe. Secondly, I intend to investigate how they were evaded by local churches in order to administer a practice of confessional coexistence impossible to eradicate, and how they have been manipulated by actors - even Protestants - to put an end to undesirable unions. Finally, I would like to present the interpretation that the Church of Rome made of Tametsi to resolve the age-old issue of mixed marriages in the Low Countries, issuing the Benedictine declaration, later applied to other contexts with a strong Protestant presence - above all outside Europe.

The Council of Trent decree, Tametsi (1563), did not explicitly mention mixed marriages and confirmed the sacramental nature of marriage between the baptised - in contrast with the protestant doctrine. ${ }^{3}$ This failure to take a position against mixed unions corresponds to a socially generalised sensitivity, since until the final decades of the sixteenth century, in places where Catholics and followers of the Reformation lived in contact with each other, marriages continued to be contracted according to criteria that, for the most part, did not take into account religious inclinations. Only when each church made access to a wedding celebration dependent upon participation on its own particular Eucharistic rite - the primary symbol of unity - did religious confession, now distinctly felt, become a potentially discriminating factor (albeit not an exclusive one) in the choice of a partner. ${ }^{4}$ Beginning in the second half of sixteenth century, Catholic synodal decrees forbade mixed marriages, as did Protestant church regulations. ${ }^{5}$ At the central level, only in 1596 the Catholic Church, with a bull issued by Clement VIII censured for the first time explicitly marriages between Protestants and Catholics, according to a policy that wanted to counteract the presence of Italian merchants in Nuremberg, intransigent in refusing the practice of Catholic worship. ${ }^{\mathbf{6}}$ Mixed marriages were associated with heresy - and subjected to the competence of the inquisition. ${ }^{7}$

Despite the prohibitions, up through the early decades of the seventeenth century, even Catholic
1 Alberigo (1991) 753-759.

2 On multinormativity Duve (2013), (2017).

3 Alberigo (1991) 753-759.

4 LüвсKE (forthcoming).

5 For examples of synodal decrees against mixed marriages, see RoskováNY (1842) I, 36. For examples of the early rules of the Protestant churches, see LüвскE (forthcoming).
See also FreIst (2017) 47: Hildesheim and Worms (1574); Bordeaux and Tours (1583); Cambrai (1586); Toulouse (1590); Narbonne and Konstanz (1609); Augsburg and Antwerpen (1610); Köln and Hertogenbosch (1612); Lüttich (1618).

6 Bullarium Romanum (1865), Tomus X, XXXVI, 280, $\$ 2$. About the policy of the Holy See towards the Italian community in Nuremberg: MölleR (1967); Bauer (1962); SEIBOLD (1984); MAZZEI (2001); ZunCKEL (2007).

7 For criminalisation of mixed marriages Cristellon (2017b). 
clergy at all levels continued to debate the liceity of mixed marriages. For example, at the end of the sixteenth century, the nuncio of Cologne asked the Congregation of the Council if a dispensation could be granted to a Catholic to marry with a "heretic", or if copulation could be allowed after the marriage was celebrated. ${ }^{8} 1602$ his successor asked the Roman Holy Office »if marriages between Catholics and heretics might be permitted in Countries where heresy flourishes with impunity", and in 1619 the bishop of Como asked "whether curates in Valtellina and Val Chiavenna could celebrate mixed marriages «. ${ }^{\text {? }}$

From the late seventeenth century forward, bishops and nuncios generally came to an awareness of the illicit nature of these unions - in contrast to some missionaries and parish priests but these higher churchmen acted as spokesmen for the practical needs of their clergy, who were confronted on a daily basis with the reality of mixed marriages.

The bishop of Coira and the Swiss nuncio, for example, while prohibiting Capuchin friars from assisting at cross-denominational marriages, reminded Rome that these unions were "celebrated in all of Germany«, where »Catholics [live] mixed with heretics«, as well as »in Calvinist countries" (1624). ${ }^{10}$ Catholic missionaries agreed to preside over mixed unions precisely because they wished to prevent the parties from resorting to a Protestant minister. ${ }^{11}$ And it should be considered that, like the Church of Rome, Protestant consistories demanded the education of children of mixed marriages in their faith and the guarantee of freedom of worship for the Protestant spouse, if not the conversion of the other spouse, and that therefore encouraging recourse to a Protestant minister increased the risk of losing a church member. ${ }^{\mathbf{1 2}}$

While their frequency varied according to the social and political context, cross-denominational marriages were nonetheless celebrated throughout the early modern period. ${ }^{\mathbf{1 3}}$

In Protestant lands or in regions of mixed confession, such marriages were celebrated before a Protestant pastor with a dispensation from the relevant consistory, ${ }^{14}$ but also by missionaries or by parish priests, despite the prohibition, or - given the frequent failure of the prohibition - they were tolerated on the condition that the children would be raised as Catholics (even if it was not always observed). ${ }^{15}$ Abbots, provosts, archdeacons, deans, and parish priests sometimes promoted these mixed unions, granting the couples a dispensation from the obligation of the reading of the banns required by the Council of Trent. They did so even though these particular officials did not have this power, which was generally reserved to the bishop and, in the case of mixed marriage, prohibited even to him. ${ }^{16}$

The requirement of parish priest at marriage, foreseen by the Council of Trent, on pain of the invalidity of the bond - and the prohibition to the
8 ASV (Archivio Segreto Vaticano), Congr. Concilio, Misc. Cod. Ext. 1, c. $418 \mathrm{r}$.

9 "An curati Vallistellinae, et valis Clavenne possint tuta conscientia celebrare matrimonia heretici cum catholica, seu catholicae cum heretico." ACDF (Archivio della Congregazione per la Dottrina della Fede), SO, DM, 1663-1722, II, Lucerna seu Retia, c. 58 .

10 Ibid., c. 59.

11 Ibid.

12 Essential in this regard are the studies of Freist (2001) and (2002). On the fear that excessive strictness might lead to recorse to a Protestant pastor, see also Dompnier (2009) 23-38. For a paradigmatic example, ACDF, SO, St. St., MM5g, fasc. 5. On condition for dispensation required by the Roman Inquisition CRISTELlON (2013a) and (2013b).
13 For the bibliography on mixed marriages, see Freist (2017); Cristellon (2016) and (2017b), Scholars of mixed marriage are agreed on the impossibility of determining the extent of the phenomenon because until a certain period these unions were not considered as such, because of gaps in the records, and because these marriage were not always recorded as mixed, sometimes by the express desire of the religious authorities.

14 Freist (2002).

15 The Holy Office explicitly prohibited parish priests to celebrate mixed marriages, so that, in uniformly Catholic countries, in granting dispensations mixtae religionis care was sometimes taken to notify the bishop sponsoring the dispensation request that »it is granted also to you, or to the person you designate, the power to attend the said wedding, without in- curing any ecclesiastical sanction, so long as all of the conditions are fulfilled « that were required for the dispensation: see ACDF, SO, MM, b. 4 (1766-1777), 1770, IV, Genova, c. 287 . Examples of weddings celebrated by missionaries APF (Archivio di Propaganda Fide), Scritture Riferite nei Congressi, Germania e Missioni Settentrionali, vol. 1 (1622-1680), c. 105, Lüneburg e Brunswick, 1682; for Danish, Dutch, and Swiss cases, see respectively ibid., c. 110, Danimarca 1686; ACDF, SO, St. St., UV 54, fasc. 10 (for Holland); ibid., DM, 1603-1722, fasc. 3, cc. 58-59.

16 This is lamented in Schannat (1771) $\S X V, 1651,772$. 
parish priest himself to celebrate mixed marriages, had to constitute a deterrent to bi-denominational unions - and make them worthless for the Catholic Church if they were contracted in contempt of the Tridentine decrees - at least in the regions where the Tametsi had been published, but also in those where it had been introduced by custom, as in the mission territories, where the missionaries carried out the functions of the parish priest.

Mixed marriages took place even in the regions where the conciliar decrees had been incorporated into secular law - as in the Italian Peninsula. They were celebrated with dispensation from the Inquisition - starting from the end of the eighteenth century; with dispensation of the Penitentiary; but also resorting to a stratagem, in times when obtaining dispensation from the inquisition was almost impossible. ${ }^{17}$

To circumvent the prohibitions mixed couples could achieve their objective with a "surprise « or »unruly« wedding, which, although it carried serious sanctions, was nonetheless valid. ${ }^{\mathbf{1 8}}$ While the Council of Trent established that the parish priest had to be present at the celebration of a wedding, the Congregation of the Council affirmed that he need not be there willingly. The jurisprudence regarding surprise marriages originated with a Toledan suit over the validity of a marriage celebrated without the priest present uttering a single word. The Congregation declared the marriage valid because the sacrament demanded ad substantiam - and the bond ad validitatem - only that the priest hear the words of consent (1580). ${ }^{19}$ It did not matter if he pretended not to have heard, or if he fled just as the groom expressed his consent as long as the bride managed to say, »I, too « while nodding her head. Nor was it even an impediment if the priest was lured to the house of one of the parties by deceit (for example, on the pretext of hearing the confession of someone who was ill), ${ }^{\mathbf{2 0}}$ or if the marriage was contracted before the proper parish priest, but in a church other than the parish church. $^{21}$
This type of wedding celebration, made famous by Alessandro Manzoni in his novel I promessi sposi, was fully valid, it is amply documented across Europe during the entire period under consideration here and involved people at every level of society. ${ }^{22}$ It was a device used to circumvent external interference - particularly the opposition of relatives. In Italy it was sometimes used to contract marriages of mixed denominations.

In 1725, for example, the bishop of Pisa informed the Holy Office that in Livorno »a heretic and a Catholic widow«, after a long period of "scandalous" cohabitation, had, during mass, as the priest turned to the faithful requesting them to pray, declared that they took each other as husband and wife, after which they withdrew »to a village«, where they lived »as a married couple«.

This couple chose a path that made them immediately suspect of heresy in the eyes of the bishop of Pisa and on the basis of the bulla of Clement VIII.

While the Holy Office was not noted for an attitude of openness toward mixed marriages, the officials did not feel it appropriate to proceed against the couple and remanded the case to the bishop - to whom they recommended, however, that the couple not be permitted to cohabit, because it constituted »a pernicious example « fraught with »the most serious consequences«. Unable to nullify the marriage of two people of different confessions - which while illicit was still valid the bishop instead imposed a separation. ${ }^{23}$

The surprise marriage was not always successful: in fact, as stipulated with a scam, it had to take place in the presence of all the qualifying elements of the sacrament, first of all the parish priest - or who legitimately took his place. ${ }^{24}$ The surprise marriage contracted between a Genoese Catholic and an English Protestant resident in Livorno, for example, was declared null. The couple had traveled to the diocese of Carrara for an impromptu marriage, believing that the groom's nationality exempted him from observance of the decrees of
17 Cristellon (2009), (2013a), (2013b).

18 Lombardi (2001) 117; SeIdel Menchi (2004)

19 Synopsis variarum resolutionum ex selectioribus decretis Sacre Congregationis Concilii collecta per materias ordine alphabetico disposita ..., (Synopsis) vol. 2, c. 86 (1580).
20 Ibid (1696).

21 Ibid. c. 87 (1697).

22 See for example Cozzi (1976) 187-189, 207-212; De Biase (1994) 375-426; Moscarda (2000). On another case discussed by the Congregation of the Council see also D’Avray / Menski (2016).
23 ACDF, MM 3, 1725 e 1726 Positio XIX Pisa e Genova.

24 Cristellon (2009). 
the Council of Trent, which had not been published in England, and that it was therefore sufficient to contract marriage before a public official, "which, in the case of marriage, is the parish priest «, and witnesses. The bishop of Pisa, however, declared the marriage null with the approval of the Holy Office, probably on the basis of the long widespread rule that a couple planning to wed was not subject to the jurisdiction of their parish of origin but to that of residence. ${ }^{25}$ In addition to confirming the bishop's decision, the Holy Office instructed the archbishop of Genoa, the bride's city of origin, to forbid the couple to cohabit should they move into his diocese. While assuring the Holy Office of his complete cooperation, the bishop of Genoa used an expression that betrayed a certain lack of clarity on the boundary between nullity and illegality of marriage: he said that he would do everything possible to keep the woman from living with her »husband .

About thirty years earlier, in Torino, a Catholic man and a »heretica also contracted marriage in this way before a parish priest not their own, but they were shrewd enough to have it ratified - also by surprise - by proxy before the vicar general while he celebrated mass. ${ }^{26}$ During the ceremony, these agents left letters of proxy on the altar, thus assuring the validity of the bond. Nevertheless, the woman had to be punished with a penitentia salutari arbitrio episcopi. ${ }^{27}$

Mixed couples were not always able to bypass the Tridentine norms. An English Protestant captain and a Catholic from Livorno had been married in Livorno in front of a Protestant pastor. When, after two years (1680), news came to the archbishop of Pisa, he declared the marriage invalid, ordering the separation. The captain therefore resigned himself to recanting his faith - while continuing in fact to »behave as a Protestant « - by marrying the woman according to the rituality prescribed by the council. ${ }^{28}$

If in uniformly Catholic countries the church of Rome had an easy game of imposing its authority, in the regions of mixed confession, or in those where the Catholic presence did not have an official recognition, a too severe attitude towards mixed marriages could compromise on the spot the fragile balance of Catholics with the consistory and, in the Empire after 1648, even be interpreted as a serious violation of religious Peace of Westphalia, which provided for the equality of the three officially recognised confessions. ${ }^{29}$

Thus, for example, in the diocese of Hildesheim, a Catholic widow, after being denied a dispensation from the second degree of affinity (according to the Council of Trent ${ }^{30}$ ) despite the fact that she was pregnant (a fact that made the case very delicate, since the legitimacy of the offspring was in question), resorted to the Protestant minister, who celebrated the marriage, with the permission of the superintendent of Salzgitter. ${ }^{31}$ The bishop imposed the separation on the couple, but in vain so that he had the woman arrested; but he also presented a request for dispensation to Rome, foreseeing a reaction from the consistory, which, as had already happened in the past, was not delayed. ${ }^{32}$ A dense correspondence followed, in which the consistory, the vicar, the nuncio, the Secretariat of State, the Holy Office took part - a correspondence made rather of opposition than of
25 Ibid. For the importance of the parish of residence see also D'Avray / Menski (2016).

26 The presence of the vicar makes the marriage valid, since it has jurisdiction over the whole diocese.

27 ASV, Synopsis, c. 85: Matrimonium vero inter catholicum et hereticam coram parocho non proprio alicuius ex contrahentibus celebratum, deinde ratificatum per procuratorem utriusque, coram testibus et vicario generali missa celebrante dum vertit se ad populum pro dicendo orate fratres, relictis procurationibus super altare fuit validum declaratum, etiamsi vicarius testerur non bene intellexisse, quid procuratores nomine sponsorum dixerint in illo actu, imposita tamen mulieri penitentia salutari arbitrio epicopi. Taurinen. matrimonii 28 septembris 1697.

28 Villani (2005) 385-386.

29 Freist (2001).

30 According to the provisions of the council, it could not be dispensed from the second degree except in the case of "great princes" and in the public interest. Alberigo (1991), Concilium tridentinum, Sessio XIV De reformatione circa matrimonium, cap. V, 758.

31 Martin Christoph Gerhard Chrysander (1716-1784). Hildesheim was a
Lutheran city with a Catholic sovereign. The Catholics were refused membership of parish of their own. About their place of residence they were assigned to a Lutheran parish church. See DürR (2006) 42-43.

32 The vicar forwarded the correspondence exchanged about a year before with the consistory for a similar case from Münster - in which case the groom was Catholic - which had been resolved with the conversion of the woman to Catholicism. The arguments put forward in the case of Hildesheim are in line with those previously presented in the case of Münster. 
dialogue, of conflicts of competences, of firmness of positions, however much both the Catholic and Protestant sides tried to corroborate their positions even referring to each other's doctrinal positions. ${ }^{33}$

While the nuncio of Cologne pointed out that Luther himself had forbidden marriage in the second degree of affinity, the consistory mentioned the decrees of the Council of Trent, which recognised to the pope the power of dispensation even to the second collateral degree - implicitly encouraging the vicar to follow up the necessary procedure to obtain the papal grace. ${ }^{34}$ It then invoked common sense by appealing to a decision of the theological faculty of Wittenberg (1694), which had proved tolerant in the union already contracted to a forbidden degree, imposing a fine on offenders rather than separation. ${ }^{35}$ Both parties referred to the Treaty of Westphalia - which had established the parity of the three main confessions of the Empire - to corroborate their position: the vicar and the nuncio had denied the dispensation from the degrees of kinship in the case of mixed unions stating their not having jurisdiction over Protestants, thus demanding the conversion in order to grant the union and refuting the notion that the reformed authorities had the right to dispense in cases involving Catholics; ${ }^{36}$ the consistory, on the other hand - aware of "how little we would have left if our peace and prosperity depended on the supreme head of the Catholic Church " - to claim »those same rights and benefits that Catholics enjoy in their churches", including the right to release dispensations and to object to the fact that the marriage contracted by one of their members was declared invalid by a Catholic authority. By virtue of »religious peace «, "the Catholic superiors" were, according to the consistory, exempt from the obligation »to follow similar pontifical provisions«, »reduced to a legal inactivity« by the laws of the
Empire, ${ }^{37}$ aimed at preventing the fragile balance on which the cohabitation between the members of the different confessional churches was based. The prelates in partibus were well aware of this. They were divided between the obligation of obedience to Rome, the demands of political convenience and the performance of their own pastoral function. Even when they applied the strict Roman directives as in the case of Hildesheim just examined, they did not cease to ask for special faculties to dispense with diriment impediments in the case of mixed unions, or to »allow marriage between Catholics and heretics" to which they did not could oppose. ${ }^{38}$

A particularly complex case is represented by the Netherlands, where the Council of Trent decrees had already been published prior the introduction of the Reformation. Marriages that were not celebrated before a parish priest had to be considered null and void for Catholics. This put Catholics in conflict with the secular authority, since, in the United Provinces, in order to be valid, marriage had to be contracted in the town hall before the civic official or in church by a Calvinist pastor which latter method was also preferred by Catholics, both because marriages celebrated according to a religious rite were significantly less expensive ${ }^{39}$ and because Catholics continued to consider the churches their own, despite being used for Calvinist worship after the Reformation. ${ }^{40}$ In some of the United Provinces, laws required Catholics to contract marriage in Calvinist churches before Calvinist ministers. The couples could then renew their vows before the Catholic parish priest. But in the case of mixed marriage, if the Catholic party asked to renew the vows before the parish priest and the non-Catholic party agreed, without, however, desiring to abjure their heresy, could the parish priest preside over the wedding? And if the heretical
33 ACDF, St. St., MM 5-g.

34 RoskovánY (1842) II, 3-4, $\$ 9$. This is most likely the case, whose provenance is not mentioned, documented in ASV, Congr. Concilio, Misc. Cod. Extern, vol. 1, cc. 446-447. For the use of the impediment of kinship as a tool to combat mixed marriages, originating from a provision of the Congregation of the Council (1597) that determined the subsequent policy of the Holy Office see Cristellon (2013a) and (2013b).
35 The sentence of Wittenberg, dating back to October 24, 1694, was taken up for example by STRYK (1699), sectio $\mathrm{V}$ de nullitate matrimonii, $\$$ XXVII, de tolerandi nuptiis cum uxori sororis filia, 219-220.

36 ACDF, St. St., MM 5-g.

37 Even in Catholic territories these laws were determined by the desire to respect customary rights such as the patria potestas, rather than by the desire to impose on the subjects the religion of the prince, as for example in the case of the Palatinate, which provided for the education of children in the religion of father although born of mixed marriages (1705). Hans (1973) 360-361.

38 More widely on this case in the context of the German Empire, Cristellon (2013a).

39 Forclaz (2009) 260; KooI (2012) 194. See also ACDF, SO, DM, 1740-1756, fasc. XI, 1749 , c. 354.

40 Frijhoff (2002) 20, 51, 119-123, 164, 169-170. 
spouse did not consent to renew the vows before the parish priest, what should be the attitude toward the Catholic spouse, who, under secular law, could not be forced to separate? ${ }^{\mathbf{4 1}}$ The practice followed by the missionaries was not to exclude them from confession, and to readmit them to communion after six months of penitence. ${ }^{\mathbf{4 2}}$ Aware that it was incapable of effectively intervening in this matter, the Holy Office decided that it was best not to respond to these uncertainties. ${ }^{\mathbf{4 3}}$

From the declaration of invalidity of these marriages, missionaries warned, »the gravest difficulties for offspring, for the missionary, for the Republic, for marriage « would follow: for children because they would be considered illegitimate; for missionaries because, accused »by the heretical side" of "preaching to invalidate these marriages", they would be forced »immediately into exile, and other grave evils«; for »the Republic because infinite disputes and confusion would take place « regarding inheritance; for marriage because the certainty of obtaining an annulment would encourage seduction by those Catholic men "who, living according to the flesh, would marry a heretic woman, and having enjoyed her and wasted her patrimony would abandon her and flee to Catholic territory, where they could easily contract a second marriage $\ll .{ }^{\mathbf{4 4}}$ Cases like these, in fact, were denounced by the Congregation of the Council; and it was further considered that, in those places where the Council of Trent decrees had been published, even Protestants could make use of Tametsi in order to obtain a divorce easily. ${ }^{45}$

The various doubts expressed to Rome for more than a century found no unitary solution, and
Roman congregations avoided a clear statement as to the validity of mixed marriages or marriages between members of the Reformed churches celebrated without parish priest.

The frequent requests for solution of doubts sent to Rome by the local churches and the delicate political and religious situation in which the region was living gave the decisive impulse to a clear and unified solution to the age-old question of marriages in the Low Countries. ${ }^{46}$ Clement XII commissioned the Congregation of the Council to draw up a detailed report on the situation in the Netherlands using the accounts of the apostolic vicar and the bishops of "Belgium « and the procedure was completed by his successor.

In the consultations that preceded the declaration of Benedict XIV (1741), it had to be decided, in particular, whether marriages contracted by Protestants and between Protestants and Catholics, in the United Provinces and in Belgium, without respecting the Tridentine decrees and therefore without a parish priest, were valid or not. ${ }^{47}$ The question of the validity of Protestants' marriage was important, in the case of conversion of only one of the spouses, who wanted to remain united to the spouse married by the Calvinist rite.

According to the prevailing opinion of the consultors, marriages contracted by heretics without respecting the decrees of the Council of Trent were certainly to be considered valid at least in contractual terms, because it was likely that the Tridentine norms did not extend to "heretical« States or communities. It is an opinion that calls into question the close link between the nuptial contract of the baptised with the sacrament, as
41 Divorce was allowed only in case of adultery or malicious abandonment. See Van der Heijden (2016) 160161. Even the consistories, however, encouraged separation or divorce in the case of confessional disparity: Koor (2012) 200.

42 ACDF, DM, Dubia 1603-1722, fasc. XXXVI, Olanda. cc. 373-374. For marriages celebrated by missionaries see for examples ACDF, SO St. St., UV 54, fasc. 10.

43 ACDF, DM, 1603-1722, Fasc. IX, cc. $379-380$, and especially c. 380 for quotations (in Latin in the original text). See also ACDF, SO, St. St., UV 54, fasc. 10, n. c.; ACDF, SO, St. St., Stanza Storica L 4-m, "Nella causa di matrimonio del duca di Wirtemberg, Sommario A, 1671 Olanda«. On the practice of not deciding see WINDLER (2013) 314.

44 ACDF, SO, St. St., UV 54, fasc. 10.

45 ASV, Congr. Concilio, Libri Decret., vol. 2, (1575-81), cc. 32-33, n. 51, Daventrinensis, s. d. For Protestant use of the Tridentine decrees in this way, see ASV, Congr. Concilio, Misc. Cod. Ext., vol. 1, cc. 402-403, s. d. (Augusta).

46 On the Dutch Church in the eighteenth century see Abels / De Groot (2015).

47 ASV, Congr. Concilio, Libri Decretorum, vol. 91, cc. 279-369v preserves the printed text of the Benedictina
Declaration De matrimoniis inter hereticos ac inter haereticos, et catholicos initis in Foederatis Belgii Provinciis dissertationes theologicae, et canonicae Reverendissimi P. D. Cavalchini Archiepiscopi Philippensis et Sacrae Congregationis concilii a Secretis, nec non quatruor insignium theologorum Romae MDCCXLI, Typis et sumptibus Hieronymi Mainardi (From now on: Benedictina). 
definitively established at Trent. ${ }^{48}$ Yet the Council was to be interpreted not according to the letter, but according to the spirit. Adopting an opinion already expressed by the missionaries, ${ }^{49}$ the consultors tended to favour the validity of marriages contracted by a civil official or Protestant pastor, affirming that this was fully within the spirit of the Council of Trent's decree Tametsi. With Tametsi, in fact, the Church had wanted to put an end to the practice of clandestine marriage, by imposing the presence of the parish priest and witnesses. The presence of a civil official or Calvinist pastor in the United Provinces guaranteed the publicity of the union in its own way and prevented clandestine marriages, therefore they could be considered as an equivalent to a parish priest for providing validity to the marriage. ${ }^{50}$ If the marriages of non-Catholics stipulated in absence of the parish priest were to be considered invalid, those who contracted them would be de facto guilty of fornication and concubinage, which would contradict the spirit of the Council Fathers. ${ }^{\mathbf{5 1}}$

Even if Tametsi had been published, the custom of the »heretics« of celebrating marriage without respect for the Tridentine decrees would have had the effect of abrogating the ecclesiastical law. Custom, in fact, prevailed over ecclesiastical law, providing the custom (a) was reasonable, (b) was known to the Pope, (c) was in force for sufficient time and (d) had the - at least implicit - consent of the sovereign pontiff.

There could be no doubt that the custom of not following the Council in nuptial matters was reasonable, because heresy rejected parish priests and conciliar decrees: marriages contracted in absence of parish priests and in defiance of Tametsi were nevertheless valid and the children born to them were therefore to be considered legitimate. Heresy itself was of course unreasonable, but not everything that proceeded from it. And since »natural reason« imposed the choice of the lesser evil among several possible evils, the only reasonable solution was to abrogate a law whose application had no effect against heresy, but which led to the stipulation of "permanently adulterine marriages, and constituted an expedient of seduction, giving rise to bigamy«. The authority of St Thomas
Aquinas - for whom positive human law lost its effect when it turned out to be not only useless but dangerous - supported this opinion.

Since many requests for the solution of doubts had been submitted to Rome, the prevailing custom in the United Provinces was undoubtedly known to the pope, who had given it de facto approval by implicitly tolerating it: never, in fact, had the praxis been explicitly forbidden by the Holy See, nor had the missionaries or Vicars Apostolic been instructed to regard it as null and void - or at any rate not as regards general case law, but only in individual cases.

It was, on the contrary, a custom introduced by the Vicar Apostolic of Holland. That prelate, in fact, did not oblige converted couples to remarry in accordance with the Tridentine legislation, but admitted them to the sacraments tamquam valide coniuncti.

Since the pope is aware that many »inconveniences" would arise from any attempt to apply the Tridentine decrees in the region, he would be acting imprudently were he to oppose their abrogation in the Netherlands: and since imprudence is not a characteristic of the pontiff, it may be presumed that he implicitly approves the praxis of marriage stipulated in the absence of the parish priest, albeit publicly. The decrees of the various Congregations do not avail to contradict his tacit assent because, as we gather from the account of the titular bishop of Castoria, no enactment later than 1671 censured it: and, since forty years are sufficient to transform a usage into a custom it lasted very well, with all its juridical consequences. The question was addressed as in a matrimonial cause, with arguments for and against the bond. On the basis of immemorial tradition it was held that the matrimonial cause - the procedure that determined whether a marriage was valid or not was gravissima et favorabilis; in this extremely delicate matter, in cases of doubt it was obligatory to incline in favour of, rather than against, the matrimonial bond. Proofs against the validity of the marriage could not be held as conclusive. No sentence of nullity could be regarded as definitive, because there must always be left open the possibility of a reconciliation between the spouses. ${ }^{52}$

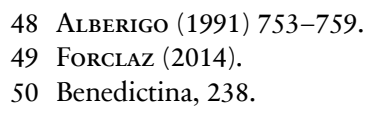

51 Benedictina, 216.

52 Cristellon (2017a) 59. 
Even though in the past these marriages had been held insufficient, one was led to understand, the time was now ripe for the sufficiency of such unions to be recognised.

On 4 November 1741, Benedict XIV declared that in the United Provinces marriages between Protestants and mixed marriages contracted without the formalities prescribed by the Council of Trent were valid. This was extended later to other territories that had a strong Protestant presence, in Europe and in non-European countries. ${ }^{53}$

As we have seen, although the Council of Trent claimed to fix a homogeneous and flawless nuptial ritual, the various local practices did not always adapt to it. They bypassed it, sometimes refused it. This led parish priests and missionaries to turn to Rome for the resolution of concrete cases. The decisions taken for individual cases became a normative reference point. It was produced by the continuous interaction and negotiation with local churches and went on in fact to profoundly influence the sacramental rituality of marriages, which Trent had claimed were fixed and immutable.

\section{Bibliography}

- Abels, Paul H.A.M., Aart De Groot (2015), The Eighteenth Century, in: Selderhuis, Hermann (ed.), Handbook of Dutch Church History, Göttingen, 361-434

- Alberigo, Giuseppe et al. (1991), Conciliorum Oecumenicorum Decreta, Bologna

- Bauer, Lothar (1962), Die italienischen Kaufleute und ihre Stellung im protestantischen Nürnberg am Ende des 16. Jahrhunderts, in: Jahrbuch für fränkische Landesforschung 22, 1-18

- Bullarium Romanum (1865), Tomus X, Augusta Taurinorum

- Cozzi, Gaetano (1976), Padri, figli e matrimoni clandestini (metà sec. XVI - metà sec. XVIII), in: La cultura 14, 169-213

- Cristellon, Cecilia (2009), Does the Priest Have to Be There? Contested Marriages Before Roman Tribunals. Italy, Sixteenth to Eighteenth Centuries, in: Österreichische Zeitschrift für Geschichtswissenschaften 3, 10-30

- Cristellon, Cecilia (2013a), L'inquisizione, il duca di Neoburgo e l'inquisizione in Germania in Età moderna, in: Rivista Storica Italiana CXXV,1, 76-108

- Cristellon, Cecilia (2013b), >Unstable and Weak-Minded or a Missionary? Catholic Women in Mixed Marriages (15631798), in: Gottschalk, Karin (ed.), Gender Difference in European Legal Cultures. Historical Perspectives. Essays presented to Heide Wunder, Stuttgart, 83-93

- Cristellon, Cecilia (2016), Mixed Marriages in Early Modern Europe, in: Seidel Menchi, Silvana (ed.), Marriage in Europe 1400-1800, Toronto, 294-317

- Cristellon, Cecilia (2017a), Marriage, the Church, and its Judges in Renaissance Venice, 1420-1545, London

- Cristellon, Cecilia (2017b), Between Sacrament, Sin and Crime: Mixed Marriages and the Roman Church in Early Modern Europe, in: Gender and History 3, 605-621

- d'Avray, David, Werner Menski (2016), Authenticating Marriages: The Decree Tametsi in a Comparative Global Perspective. Max Planck Institute for European Legal History Research Paper Series No. 2016-03, online http://dx.doi.org/10.2139/ ssrn.2754003

- De Biase, Luca (1992), Amore di Stato. Venezia. Settecento, Palermo

- Dompnier, Bernard (2009), L'administration des sacrements en terre protestante à la lumière des facultates et des dubia des missionaires (XVIIe-XVIIIe siècle), in: Broggio, Paolo et al. (eds.), Administrer les sacrements en Europe et au Noveau Monde: la curie romaine et les dubia circa sacramenta. Mélanges de l'École française de Rome 121,1, 23-38

- Dürr, Renate (2006), Politische Kultur in der Frühen Neuzeit: Kirchenräume in Hildesheimer Stadt- und Landgemeinden 1550-1750, Gütersloh

- Duve, Thомas (2013), Die Justiz vor den Herausforderungen der kulturellen Diversität - rechtshistorische Annäherungen: Einführung in die Ringvorlesung des LOEWE-Schwerpunkts »Außergerichtliche und gerichtliche Konfliktlösung«, WS 2013/ 2014, FB 01 Rechtswissenschaft der Goethe-Universität, in: LOEWE-Schwerpunkt. »Außergerichtliche und gerichtliche Konfliktlösung « 7, 1-15, online http://publikationen.ub.uni-frankfurt.de/frontdoor/index/index/docId/29166

- Duve, Thomas (2017), Was ist »Multinormativität«? - Einführende Bemerkungen, in: Rechtsgeschichte - Legal History Rg 25, 88-101, online http://dx.doi.org/10.12946/rg25/088-101

53 The issue of mixed marriages in the Netherlands, the enactment of the Benedictine declaration and its extension into European and extra-
European territories is treated more widely in a chapter of the book on mixed marriages that I am concluding. 
- Forclaz, Bertrand (2009), The Emergence of Confessional Identities: Family Relationships and Religious Coexistence in Seventeenth-Century Utrecht, in: Dixon, C. Scotr et al. (eds.), Living with Religious Diversity in Early Modern Europe, London, 250-266

- Forclaz, Bertrand (2014), Catholiques au défi de la Réforme. La coexistence confessionnelle à Utrecht au XVIIe siècle, Paris

- Freist, Dagmar (2001), Zwischen Glaubensfreiheit und Gewissenszwang, in: Asch, Ronald G. et al. (eds.), Frieden und Krieg in der Frühen Neuzeit. Die europäische Staatenordnung und die außereuropäische Welt, München, 293-322

- Freist, Dagmar (2002), One Body, Two Confessions: Mixed Marriages in Germany, in: Rublack, Ulinka (ed.), Gender in Early Modern German History, Cambridge, 275-305

- Freist, Dagmar (2017), Glaube - Liebe - Zwietracht. Konfessionell gemischte Ehen in Deutschland in der Frühen Neuzeit, Oldenburg

- Frijhoff, Willem (2002), Embodied Belief. Ten Essays on Religious Culture in Dutch History, Hilversum

- Hans, Alfred (1973), Die kurpfälzische Religionsdeklaration von 1705. Ihre Entstehung und Bedeutung für das Zusammenleben der drei im Reich tolerierten Konfessionen, Mainz

- Kooi, Christine (2012), Calvinists and Catholic during Holland's Golden Age, Cambridge

- Lombardi, Daniela (2001), Matrimoni di Antico Regime, Bologna

- Lüвске, DAvid (forthcoming), Making Marriages Mixed. Religious Pluralization, Ritual, and the Formation of Intra-Christian Marriage Barriers in Late Sixteenth- and Early Seventeenth-Century Germany, in: Cristellon, Cecilia (ed.), Mixed Marriages in Europe. The politic and practices of Religious Plurality in Europe between the Fourteenth and Nineteenth Centuries

- Mazzei, Rita (2001), Convivenza religiosa e mercatura nell'Europa del Cinquecento. Il caso degli italiani a Norimberga, in: Méchoula, Henry et al. (eds.), La formazione storica della alterità. Studi di Storia della tolleranza nell'età moderna offerti a Antonio Rotondò, vol. 1, Firenze, 395-428

- Möller, Bernd (1967), Protestant Dogma and the City Government: the Case of Nuremberg, in: Past and Present 36, 35-58

- Moscarda, Dea (2001), Il cardinale Giovan Battista de Luca giudice rotale e la causa matrimoniale tra Michele de Vaez e Giovanna Maria de Sciart (Napoli 1650), in: Seidel Menchi, Silvana, Diego Quaglioni (eds.), Matrimoni in dubbio. Unioni controverse e nozze clandestine in Italia dal XIV al XVIII secolo, Bologna, 415-429

- Roskovány, Ágostín (1842), De matrimoniis mixtis inter catholicos et protestantes, vol. I, Quinque-Ecclesiis

- Schannat, Johannes Fridericus (1771), Concilia Germaniae, Köln

- Seibold, Gerhard (1984), Zur Situation der italienischen Kaufleute in Nürnberg während der zweiten Hälfte des 17. und der ersten Hälfte des 18. Jahrhunderts, in: Mitteilungen des Vereins für die Geschichte der Stadt Nürnberg 71, 186-207

- Seidel Menchi, Silvana (2004), Il matrimonio finto. Clero e fedeli post-tridentini tra sperimentazione liturgica e registrazione di stato civile, in: Seidel Menchi, Silvana, Quaglioni, Diego (eds.), Trasgressioni: Seduzione, concubinato, adulterio bigamia (XIV-XVIII secolo), Bologna, 535-571

- Stryk, Samuel (1699), Tractatus de dissensu sponsalitio, Wittenbergae

- Van der Heijden, Manon (2016), Marriage Formation: Law and Custom in the Low Countries 1500-1700, in: Seidel Menchi, Silvana (ed.), Marriage in Europe 1400-1800, Toronto, 156-175

- Villani, Stefano (2005), Donne inglesi a Livorno nella prima età moderna, in: Frattarelli Fischer, Lucia, Olimpia Vaccari (eds.), Sul filo della scrittura. Fonti e temi per la storia delle donne a Livorno, Pisa, 377-399

- Windler, Christian (2013), Uneindeutige Zugehörigkeiten. Katholische Missionare und die Kurie im Umgang mit >communicatio in sacris<, in: Pietsch, Andreas, Barbara Stollberg-Rilinger (eds.), Konfessionelle Ambiguität. Uneindeutigkeit und Verstellung als religiöse Praxis in der Frühen Neuzeit, Gütersloh, 314-345

- ZunCKel, Julia (2007), Esperienze e strategie commerciali di mercanti tedeschi fra Milano e Genova nell'epoca della controriforma, in: Burkhardt, Albrecht et al. (eds.), Commerce, voyage et expérience religieuse, Rennes, 231-255 